\title{
A FAMILY OF HOLOMORPHIC FUNCTIONS DEFINED BY DIFFERENTIAL INEQUALITY
}

\author{
Nafya Hameed Mohammed, Ebrahim Analouei Adegani, \\ TEOdOR BULBOACĂ AND NAK EUN CHO*
}

\begin{abstract}
The aim of the present paper is to introduce and study a subfamily of holomorphic and normalized functions defined by a differential inequality. Some geometric properties of this family of holomorphic functions and different problems of a family of such functions are presented.
\end{abstract}

\section{Mathematics subject classification (2020): Primary 30C45, Secondary 30C80.}

Keywords and phrases: Differential subordination, logarithmic coefficients, uniformly starlike and uniformly convex functions, convex, starlike and univalent functions, coefficient inequalities, Fekete-Szegő functional, Hankel determinant.

\section{REFERENCES}

[1] D. Alimohammadi, N. E. Cho, E. A. Adegani, A. Motamednezhad, Argument and coefficient estimates for certain analytic functions, Mathematics, 8, 1 (2020), Article ID 88.

[2] D. Alimohammadi, E. A. Adegani, T. Bulboacă, N. E. Cho, Logarithmic coefficients for classes related to convex functions, Bull. Malays. Math. Sci. Soc., 44, (2021), 2659-2673.

[3] D. Alimohammadi, E. A. Adegani, T. BulboaCă, N. E. Cho, Logarithmic coefficient bounds and coefficient conjectures for classes associated with convex functions, J. Funct. Spaces, 2021, (2021), Article ID 6690027, 7 pages.

[4] E. A. AdEgANI, N. E. CHO, M. JAFARI, Logarithmic coefficients for univalent functions defined by subordination, Mathematics, 7, 5 (2019), Article ID 408.

[5] L. BIEBERBACH, Über die Koeffizienten derjenigen Potenzreihen, welche eine schlichte Abbildung des Einheitkreises vermitteln, S.-B. Preuss. Akad. Wiss., 138, (1916), 940-955.

[6] L. DE BRANGES, A proof of Bieberbach conjecture, Acta Math., 154, (1985), 137-152.

[7] P. L. Duren, Univalent Functions (Grundlehren der mathematischen Wissenschaften 259, New York, Berlin, Heidelberg, Tokyo), Springer-Verlag, Berlin/Heidelberg, Germany, 1983.

[8] A. Ebadian, T. Bulboacă, N. E. Cho, E. A. Adegani, Coefficient bounds and differential subordinations for analytic functions associated with starlike functions, Rev. R. Acad. Cienc. Exactas Fís. Nat. Ser. A Mat. RACSAM, 114, (2020), Article ID 128.

[9] A. Ebadian, N. H. Mohammed, E. A. Adegani, T. BulboaCă, New results for some generalizations of starlike and convex functions, J. Funct. Spaces, 2020, (2020), Article ID 7428648.

[10] S. KanAS, Subordinations for domains bounded by conic sections, Bull. Belg. Math. Soc. Simon Stevin, 15, (2008), 589-598.

[11] S. Kanas, E. A. Adegani, A. Zireh, An unified approach to second Hankel determinant of bisubordinate functions, Mediterr. J. Math., 14, 6 (2017), Article ID 233.

[12] I. R. KAYUMOV, On Brennan's conjecture for a special class of functions, Math. Notes, 78, (2005), 498-502.

[13] F. R. KeOgh, E. P. Merkes, A coefficient inequality for certain classes of analytic functions, Proc. Amer. Math. Soc., 20, (1969), 8-12.

[14] V. S. Masih, A. Ebadian, S. NajafZadeh, On applications of Nunokawa and Sokót theorem for p-valency, Bull. Iranian Math. Soc., 46, (2020), 471-486. 
[15] I. M. Milin, Univalent Functions and Orthonormal Systems, Amer. Math. Soc. Transl. of Math. Monogr., 49, Proovidence, RI, 1977.

[16] I. M. MiLIN, On a property of the logarithmic coefficients of univalent functions, In: Metric Questions in the Theory of Functions, Naukova Dumka, Kiev, (1980), 86-90 (in Russian).

[17] I. M. MILIN, On a conjecture for the logarithmic coefficients of univalent functions, Zap. Nauch. Semin. Leningr. Otd. Mat. Inst. Steklova, 125, (1983), 135-143 (in Russian).

[18] S. S. Miller, P. T. Mocanu, Differential Subordinations: Theory and Applications, 225, Marcel Dekker Inc., New York, NY, USA, 2000.

[19] Z. NeHARI, Conformal Mapping, McGraw-Hill, New York, NY, USA, 1952.

[20] Сh. Pommerenke, On the coefficients and Hankel determinants of univalent functions, J. Lond. Math. Soc., 44, (1966), 111-122.

[21] D. V. Prokhorov, J. Szynal, Inverse coefficients for $(\alpha ; \beta)$-convex functions, Ann. Univ. Mariae Curie-Skłodowska Sect. A, 35, (1981), 125-143.

[22] D. RĂDUCANU, Second Hankel determinant for a class of analytic functions defined by q-derivative operator, An. Ştiinţ. Univ. "Ovidius” Constanţa Ser. Mat., 27, 2 (2019), 167-177.

[23] M. S. Robertson, A remark on the odd-schlicht functions, Bull. Amer. Math. Soc., 42, (1936), 366-370.

[24] W. Rogosinski, On the coefficients of subordinate functions, Proc. Lond. Math. Soc., 48, (1943), $48-82$.

[25] F. RøNNING, Uniformly convex functions and a corresponding class of starlike functions, Proc. Amer. Math. Soc., 118, (1993), 189-196.

[26] F. RøNNING, Some radius results for univalent functions, J. Math. Anal. Appl., 194, (1995), 319-327.

[27] Y. J. Sim, A. LECKO, D. K. ThOMAs, The second Hankel determinant for strongly convex and Ozaki close-to-convex functions, Ann. Mat. Pura Appl., 200, (2021), 2515-2533.

[28] P. Zaprawa, Successive coefficients of close-to-convex functions, Forum Math., 32, (2020), 11311141. 